\title{
Hvad konnekterer konnektorerne?
}

\author{
HENNING NøLKE \\ Institut for Sprog, Litteratur og Kultur, Aarhus Universitet, Danmark
}

\begin{abstract}
This article addresses the main question: Which elements do (pragmatic) connectors connect? Connectors are normally defined as linguistic items that combine simple utterances into more complex utterances. First I try to decircumscribe the class of connectors, which is extremely heterogeneous. Then I present the basic elements of a Connector Grammar distinguishing the connectors' arguments, which are the semantic units they combine, from their (left and right) scopes, which are the formal units that they convey. Taking the French connector donc as my key example, empirical analysis reveals that very often there is no utterance functioning as left scope. I argue that the word (donc) should still be regarded as a connector in these cases because it retains its basic semantic (connecting) function, only the left argument is implicit and has to be inferred from the preceding context: the left scope is non-verbal. To preserve a unique logic-semantic description of the connector for all its uses, I introduce the generalized syllogism, which probably can be found behind most human reasoning.
\end{abstract}

\section{INDLEDNING}

Konnektorerne, disse små størrelser der binder tekster sammen, har længe været et af lingvistikkens stedbørn. De senere års voksende interesse for syntaktiske og semantiske fænomener der går på tværs af sætningsgrænsen har imidlertid bragt dem lidt ind i varmen, og i den udenlandske lingvistiske litteratur er der dukket mange studier op af forskellige konnektorers funktion. For sprogforståelsen er konnektorerne da også et vigtigt element. De styrer i høj grad vores opfattelse af hvad der bliver sagt og afslører ofte holdninger som afsender måske endda ikke engang selv er bevidst om. Man kan spekulere på om det ikke er tilfældet i følgende autentiske eksempel:

Tidsskrift for Sprogforskning • Årgang 4 • Nr. 1-2 • 2006, pp. 155-185 
Som danskere har vi næppe svært ved at afsløre det underforståede her.

Konnektorerne knytter tekstelementer sammen - de konnekterer; men hvad er det mere præcist de konnekterer? Traditionelt taler man om at de knytter sætninger eller ytringer sammen som i (1). Fra et syntaktisk synspunkt udfører de koordination - således regnes men oftest for en sideordnende konjunktion og fra et semantisk synspunkt knytter de sætningernes indhold eller betydning sammen. Allerede et enkelt eksempel som (1) afslører imidlertid at der snarere er tale om at men forbinder "summen" af de to første sætninger/betydninger med den sidste sætning/betydning. Vi skal se nedenfor at det snarere er reglen end undtagelsen at konnektorer knytter elementer sammen der ikke på nogen enkel vis lader sig analysere i traditionelle sætningstermer, så spørgsmålet forbliver ubesvaret: Hvad konnekterer konnektorerne egentlig?

Jeg vil i det følgende koncentrere mig om fransk materiale, dels fordi det er det jeg selv har arbejdet med, og dels fordi der findes en særlig righoldig litteratur om de franske konnektorer. At forstå et fremmedsprogs konnektorer er i øvrigt ofte noget af det de sprogstuderende sidst lærer. Der er meget sjældent direkte oversættelser af konnektorer sprogene imellem, og det er overordentlig vanskeligt at forstå de ofte subtile nuancer en konnektor formidler. Dette gør selvsagt også ordbogsarbejdet meget vanskeligt. Det skyldes naturligvis primært semantisk-pragmatiske forskelle; men nærmere undersøgelser afslører at forskellene stikker dybere. De er oftest også strukturelle, og mere specifikt berører de tit spørgsmålet jeg har stillet i titlen. Det er de strukturelle egenskaber der er i fokus i denne artikel; men da de hænger uløseligt sammen med de semantiskpragmatiske, vil jeg også lejlighedsvis komme ind på disse.

Først vil jeg kortfattet opstille de vigtigste elementer en konnektorgrammatik må indeholde. Dernæst vil jeg kort omtale konnektorernes underforståede argumenter for så at koncentrere mig om selve spørgsmålet: Hvad er det for en slags størrelser konnektorerne forbinder, og hvordan finder man disse størrelser i afkodningsprocessen? Vi skal se at dette spørgsmål er langt mere kompliceret end det normalt antages. Til sidst vil jeg komme ind på nogle nye beskrivelses- 
og forklaringsmuligheder som resultaterne giver samt diskutere en række deskriptive og teoretiske problemer og konsekvenser der opstår.

\section{HVAD ER EN KONNEKTOR?}

Men først må vi selvfølgelig præcisere hvad vi egentlig forstår ved en konnektor. Det er klart at konnektorerne ikke udgør en ordklasse; de er funktionelt defineret. Et første problem består i at der ikke er enighed om hvilke størrelser der skal regnes med til konnektorerne. Konnektor er et af de begreber som vi lingvister holder så meget af at tale om, som om vi alle ved hvad det er, men hvor det, så snart det kommer til konkrete analyser, hurtigt viser sig at vi sjældent taler om helt det samme. Der synes dog at være en kerne af sproglige elementer som alle er enige om at kalde konnektorer, man kunne tale om de prototypiske konnektorer, og med afsæt i den vil jeg i denne fremstilling tage udgangspunkt i følgende funktionelle definition:

(2) En prototypisk konnektor forbinder ytringer og danner en kompleks mening ved at kombinere og specificere de enkelte ytringers meninger.

\subsection{Inventar}

En lang række forskellige grammatiske størrelser kan fungere som konnektorer. Man kan skelne mindst fire formklasser:

(3) Inventar - formklasser

- $\quad$ Konjunktioner (et, mais, or, car, puisque, comme, ...)

- $\quad$ Adverbier (donc, pourtant, ensuite, inversement, cependant, ainsi, ...)

- $\quad$ Præpositionssyntagmer (par contre, de ce fait, en effet, en fait, en revanche, d'une part ... d'autre part, ...)

- $\quad$ (Andre) faste forbindelser (ainsi que, il s'ensuit que, c'est pourquoi, ...)

Som det fremgår af denne liste, er der ikke nogen tæt sammenhæng mellem den sproglige form og den tekstuelle konnektorfunktion. Det er sikkert heller ikke alle lingvister og grammatikere der vil henregne alle de nævnte størrelser til konnektorerne. Kun konjunktionerne synes at være "født" til at fungere som sådanne; men som vi skal se er det endda også for dem kun i visse anvendelser de lever op til definitionen foreslået i (2). 


\section{HENNING NøLKE}

\subsection{Afgrænsningsproblematikken}

Afgrænsningsproblemerne skyldes for det første en uklarhed i selve formuleringen af (2): Hvad forstår man ved en ytring? Det er måske ret klart at de sideordnende konjunktioner og og eller, der jo kan sideordne på mange syntaktiske niveauer, kun fungerer som konnektorer (efter (2)) når de sideordner (hoved?)sætninger. Der er selvfølgelig ingen grund til at tale om en konnektor i (4):

(4) Clara og Jesper har giftet sig.

hvor og blot forbinder to proprier. Men hvad med de underordnende konjunktioner? Kan de fungere som konnektorer?

(5) Clara og Peter har giftet sig fordi de skal have et barn.

(6) Clara og Peter har giftet sig, eftersom de skal have et barn.

(7) Clara og Peter har giftet sig, for de skal have et barn.

I (5) føler man vel intuitivt at der kun er én ytring, og så er fordi ikke en konnektor, medens man i (7) vel har to sideordnede ytringer. (6) synes at placere sig midt mellem de to poler, og det er næppe nogen tilfældighed at netop konjunktionen puisque ("eftersom") har været genstand for lange diskussioner af hvorvidt den underordner eller sideordner. Tilsyneladende underordner den syntaktisk, samtidig med at den samstiller to selvstændige ytringer. Der er tradition for i sådanne grænsetilfælde at opfatte konjunktionerne som konnektorer - ofte uden diskussion. Det vil jeg også gøre i denne artikel.

Et andet, og måske alvorligere problem, ligger i en uklarhed i hvad man forstår ved at forbinde to ytringer. Som følge af kohærenspostulatet vil modtager altid søge at indtolke en sammenhæng mellem to på hinanden følgende ytringer. Valget af sammenhæng styres bl.a. af alle former for kohæsive elementer (anaforer, isotopier, m.m.) og altså ikke blot af konnektorerne. Hvad med en ytring som (8):

(8) Helt aerligt, Peter er nu ikke ret god til fodbold. 
Det er klart at udsigelsesadverbialet helt aerligt knytter an til den foregående tekst og således har en konnektorfunktion. Dette er imidlertid ikke adverbialets primære funktion (som er at kvalificere sproghandlingen). Man kan derfor tale om en indirekte konnektorfunktion. Jeg har andetsteds foreslået at skelne mellem de analytiske konnektorer, hvis primære funktion er konnektorfunktion, og de syntetiske konnektorer, hvor den kun er indirekte (Nølke 1993: 133-142) ${ }^{2}$. I det følgende vil jeg kun behandle de analytiske konnektorer.

Det er ikke blot udsigelsesadverbialer der kan fungere som syntetiske konnektorer. Vi har noget lignende med de paradigmatiserende adverbialer (fokuspartiklerne) ${ }^{3}$ og med diskurspartiklerne:

(9) Politiet i Hørsholm fangede natten til i går en prøveløsladt indbrudstyv, der også var fuld. (Berlingske Tidende)

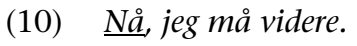

Hertil kommer at udtryk der kan fungere som konnektorer i visse sammenhænge, kan gå hen og fungere som diskurspartikler i andre:

(11) Pierre est parti. ... Et alors?

Der er faktisk ofte glidende overgange mellem konnektorerne og diskurspartiklerne ${ }^{4}$, hvilket er et fænomen der, som vi skal se, kommer til at stå centralt når man vil undersøge hvad konnektorerne knytter an til. Jeg vil derfor lade det ligge her.

\subsection{Konnektor(hoved)typer}

Konnektorerne udgør en ret heterogen mængde og der findes næppe nogen naturlig klassifikation. De kan inddeles på flere forskellige måder alt efter hvilket formål klassifikationen skal tjene. Nogle bruges til at etablere en særlig rækkefølge, andre til opremsning, henvisning osv. Nogle handler om tid, andre om kausale forhold. Nogle går på indhold, andre på form eller strukturering. Nogle tjener til forklaring, andre til illustration, eller til argumentation. Man kan dog med et vist held udskille en stor central gruppe der behandler argumentative forhold i en eller anden forstand, herunder egentlig kausalitet. Det er dem jeg vil begrænse mig til i denne artikel. Jeg vil altså se bort fra fx temporale ${ }^{5}$ og 
metalingvistiske eller -tekstuelle konnektorer, som først, derefter, se ovenfor og lignende.

Lad os kalde de kausale og argumentative (i vid forstand) konnektorer for de pragmatiske konnektorer. De falder naturligt i to klasser:

- $\quad$ Ensretterne, der bevarer argumentationsretningen.

- $\quad$ Modsatretterne, der involverer en modargumentation.

Årsags- og følgekonnektorer er eksempler på ensrettere, mens koncessive og adversative konnektorer ${ }^{6}$ er eksempler på modsatrettere.

\section{KONNEKTORGRAMMATIK}

Efter således at have afgrænset denne artikels emne: de pragmatiske konnektorer, er det tid at opstille de vigtigste elementer en konnektorgrammatik må indeholde. Denne opstilling er tilpasset de pragmatiske konnektorer og ville kræve mindre justeringer hvis man inddrog andre typer ${ }^{7}$.

\subsection{Virkefelt (scope)}

Nogle sproglige størrelser har i en eller anden forstand en indflydelse på et større eller mindre område af deres formelle omgivelser. Dette område kaldes størrelsens virkefelt (eller scope). Et virkefelt har en udstrækning og et perspektiv $^{8}$ :

- $\quad$ Virkefeltsudstrækningen er selve den streng (eller mere generelt det formelement), der indgår i virkefeltet.

- $\quad$ Virkefeltsperspektivet er det aspekt, virkefeltet ses under af den sproglige størrelse (v-elementet, her konnektoren).

En pragmatisk konnektor har dobbelt virkefelt (et venstrevirkefelt og et højrevirkefelt).

- $\quad$ Syntaktisk er konnektoren knyttet til sit højrevirkefelt.

- Dette formaliseres som: $\underline{X, K o n Y}$,

hvor $X$ og $Y$ er de syntaktiske størrelser (strenge), der udgør konnektorens virkefelter. Som det fremgår af eksemplet i (12): 
[Denne historie virker usandsynligi, ], [den er imidlertid sand $\left._{\mathrm{\gamma}}\right]$.

hvori virkefelterne er angivet med firkantede parenteser, kan konnektoren integreres helt i sit højre virkefelt - naturligvis undtaget når den udgøres af en konjunktion, der altid er spidsstillet. Man kan skelne mellem mindst fire typer perspektiv:

- $\quad$ form (fx kort sagt)

- $\quad$ udsigelse (fx helt aerligt)

- $\quad$ ytring (fx måske)

- $\quad$ proposition (fx: omhyggeligt)

\subsection{Argumenter}

Konnektorens argumenter er de semantiske størrelser den forbinder. De symboliseres med $p$ og $q$. De pragmatiske konnektorer forudsætter typisk eksistensen af en primitiv følgerelation mellem $p$ og $q$. Den primitive følgerelation er en ekstrasproglig, orienteret relation mellem de to argumenters referenter, som vi indtolker på grundlag af vor opfattelse af verden. Konventionelt benytter vi $p$ til at betegne antecedenten og $q$ postsekventen (eller konsekvensen) i denne relation. Eksemplerne i (13) illustrer dette forhold:

(13a) Il fait beau, donc Pierre se promène. 'Det er godt vejr, altså går Peter en tur.'

$(p$ donc $q)$

(13b) Pierre se promène, donc il fait beau. 'Peter går en tur, altså er det godt vejr.'

$(q$ donc $p)$

Man bemærker at donc tillader begge rækkefølger af argumenterne 9 . Derved adskiller den sig fra fx de ce fait eller c'est pourquoi der kun kan erstatte donc i (13a), med mindre man antager den modsatrettede følgerelation hvor det er Peters gåen tur der skaber det gode vejr. Som man ser, er den primitive følgerelation en form for topos der introduceres eller aktiveres mellem linierne af det sproglige udtryk.

Forholdet mellem virkefelter og argumenter er det, at argumenterne skal være af den type perspektivet angiver, og de skal udledes af den sproglige størrelse der udgør virkefeltsudstrækningen. 


\subsection{Den logisk-semantiske funktion (L-S-funktionen)}

L-S-funktionen giver instrukser for hvorledes argumenterne skal interpreteres og for hvilken kompleks mening der dannes ud fra deres (nye) meninger. L-Sfunktionen udvirker således (oftest) en geninterpretation. Man kan sige at den beskriver eller tolker argumenterne. Følgende eksempel, som jeg hørte i flyet fra Århus til København, illustrerer dette:

\section{(14) Vi håber, De har haft en kort, $\underline{\text { men }}$ behagelig rejse.}

Ved at forbinde argumenterne De har haft en kort rejse og (de har haft en) behagelig rejse med konnektoren men beskrives en kort rejse som en ubehagelig rejse eller noget i den retning. Eksemplet illustrerer i øvrigt at der sjældent er tale om præcise instrukser om gentolkning, afgørende er det her blot at en kort rejse og en behagelig rejse skal opfattes som modsætninger på en eller anden måde.

Som eksempel på formuleringen af en L-S-funktion har jeg andetsteds foreslået følgende analyse af donc:

(15) I sekvensen $X$ donc $Y$ præsenteres $Y$ som en konsekvens af $X$ fundet ved et ræsonnement.

Vi skal se i afsnit 5 at denne formulering kun dækker de "klassiske" og mest studerede anvendelser af donc.

\subsection{Strukturelle funktioner}

De strukturelle funktioner giver instrukser for etableringen af konneksionens strukturelle grundelementer. Man kan her tale om en syntaktisk funktion ud over sætningsgrænsen (Nølke 2002). Der er (mindst) tre typer strukturelle funktioner knyttet til en konnektor. De indeholder instrukser vedrørende:

- $\quad$ antal virkefelter (prototypisk to);

- $\quad$ virkefeltsperspektivtype(r);

- $\quad$ virkefelternes udstrækning: Hvor i (kon)teksten skal virkefelterne findes og hvor meget omfatter de? 
Den tredje funktion kalder jeg detektionsfunktionen. Vi skal se at medens højre virkefelt typisk ligger fast, kan detektionsfunktionen variere væsentligt fra konnektor til konnektor mht. venstre virkefelt.

Detektionsfunktionen spiller naturligvis en central rolle, når man vil forsøge at finde ud af hvad en konnektor konnekterer i konkrete tilfælde. Vi skal se at den indgår $\mathrm{i}$ et komplekst samspil både med de to andre strukturelle funktioner og med L-S-funktionen.

Med dette formelle apparat i bagagen vil jeg nu gå over til at se nærmere på to særlige fænomener knyttet til anvendelsen af konnektorer. For det første indeholder nogle konnektorers L-S-funktion underforståede argumenter; hvordan findes de? Det ser jeg kort på i afsnit 4. For det andet kan nogle konnektorer knytte an til nonverbale størrelser. Dette giver store problemer for den lingvistiske beskrivelse (og forklaring) og har måske nogle dramatiske teoretiske konsekvenser. Det handler afsnittene 5-8 om.

\section{UNDERFORSTÅEDE ARGUMENTER, EKSEMPLET MAIS?}

Næppe nogen enkelt konnektor har været genstand for så mange undersøgelser og analyser som den franske mais. Allerede i 1977 påviste Jean-Claude Anscombre og Oswald Ducrot hvorledes det franske mais sammenfatter to forskellige tekstfunktioner der på andre sprog formidles af forskellige ord. Det foranledigede dem til at skelne mellem et mais $_{\mathrm{SN}}$ svarende til spansk sino og tysk sondern (svensk utan) og et mais PA svarende til spansk pero og tysk aber (svensk men). At mais har været så populært et studieobjekt ${ }^{10}$ hænger utvivlsomt sammen med de mange subtile betydningsnuancer denne lille tilsyneladende uskyldige og højfrekvente konnektor kan skabe. Dette gælder især mais $\mathrm{PA}_{\mathrm{P}}$ som de fleste studier da også har handlet om. Også her vil jeg holde mig til denne variant.

Mais $_{\mathrm{PA}}$ er en modsatretter. Den introducerer altså et modsætningsforhold mellem sine to argumenter; men som Lakoffs berømte eksempel He is a Republican but honest viser er der langt fra tale om et rent og skært modsætningsforhold, men om en modsætning der ofte bygger på en særlig tolkning - man kunne kalde den stærkt subjektiv - af argumenterne ${ }^{11}$. I Lakoffs eksempel introduceres der et direkte modsætningsforhold mellem det at være republikaner og det at være 
ærlig. Ofte er tolkningen imidlertid endnu mere kompliceret og flere læsninger er mulige som i (16):

\section{(16) Peter er smuk, men han er fattig.}

Her er det vanskeligt at forestille sig et direkte modsætningsforhold mellem det at være smuk og det at være fattig; det er næppe sådan at smukke mennesker normalt er rige. Modsætningen er mere indirekte. Det er den type eksempler Anscombre og Ducrot har arbejdet med i snart 30 år. De har foreslået en analyse der involverer eksistensen af et tredje argument, $r$. Deres analyse bliver så, kort skitseret:

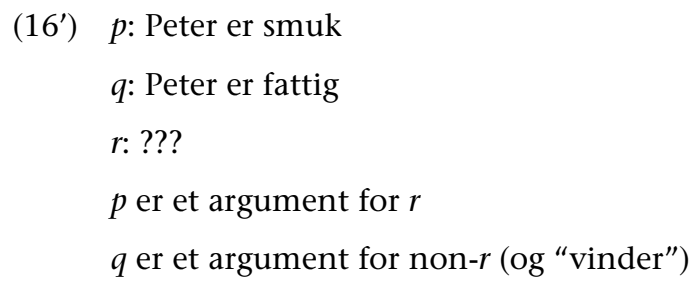

Det tredje argument er implicit eller "skjult", og modtager må selv finde ud af hvad det er. Ofte vil man naturligvis blive vejledt af konteksten; men det kan også forekomme at man virkelig er i tvivl. I (16) kunne $r$ fx være 'Peter er en attraktiv ægtemand'; men det kunne sikkert lige så godt være noget helt andet. Eneste restriktion på argumentet $r$ er at det skal kunne gå ind i analysemønstret i $\left(16^{\prime}\right)$. Mais er således et slående eksempel på hvor kontekstfølsomme konnektorerne kan være.

Man kan tale om at mais (altså mais $_{\mathrm{PA}}$ ) har to anvendelser; den kan introducere en indirekte modsætning som i eksempel (16) eller en direkte modsætning som i Lakoffs eksempel. Begge typer kan imidlertid analyseres ved hjælp af (16'). I den direkte modsætning gælder det blot at $r$ bliver lig med $q$ 's negation. Flere forskere (fx Moeschler 1985) har påvist at mais adskiller sig fra andre modsatrettere som fx pourtant og cependant, som den ellers ligger tæt op ad i betydning, netop ved at kunne introducere et indirekte modsætningsforhold. Det gælder altså at medens man tit har en implicit slutningsregel (et topos/en primitiv følgerelation), så er det særlige ved mais at denne indeholder et implicit argument, der fungerer som en slags "vadesten" i modsætningen. 


\section{VENSTRE VIRKEFELT}

Et andet og langt mere udbredt fænomen består $i$ at det kan være vanskeligt at afgøre hvilke elementer konnektorerne faktisk binder sammen i konkrete tilfælde: Hvordan finder man deres argumenter, eller med andre ord, hvordan virker deres detektionsfunktion? Dette problem har ejendommeligt nok næsten ikke været genstand for undersøgelser. Langt de fleste studier af konnektorerne synes at have taget for givet at argumenterne er lette at finde, og har fokuseret på at beskrive deres L-S-funktion. Det hænger utvivlsomt sammen med at så mange studier har taget udgangspunkt i konstruerede eksempler eller har arbejdet med konnektorer der ikke volder store problemer på dette punkt. Ser man imidlertid nærmere på mere komplicerede tekster, måske især litterære tekster, og på deres anvendelse af de små og hyppige konnektorer som fx mais og donc, viser situationen sig dog at være mere kompleks.

Højre virkefelt volder normalt ikke problemer. Det udgøres i langt de fleste tilfælde simpelthen af den sætning som konnektoren er syntaktisk tilknyttet. Dette synes i det mindste at være tilfældet for de pragmatiske konnektorer, som jeg koncentrerer mig om her ${ }^{12}$. Venstre virkefelt er der til gengæld ofte ret vide rammer for. Det er faktisk langt fra altid at det udgøres af sætningen umiddelbart foran konnektoren, sådan som det måske umiddelbart kunne forventes. I følgende tekststykke fra Gustave Flauberts Madame Bovary er det, i en nærliggende læsning, hele tre sætninger $\mathrm{væk}^{13}$ :

(17) Emma se repentit d'avoir quitté si brusquement le percepteur. $\left[_{\mathrm{x}(\mathrm{p})}\right.$ Sans doute, il allait faire des conjectures défavorables $\left.\mathrm{x}_{\mathrm{X})}\right]$. L'histoire de la nourrice était la pire excuse, tout le monde sachant bien à Yonville que la petite Bovary, depuis un an, était revenue chez ses parents. D'ailleurs, personne n'habitait aux environs; ce chemin ne conduisait qu'à la Huchette; ${ }_{\mathrm{Y}(q)}$ Binet donc avait deviné d'où elle venait $\left._{\mathrm{Y}(q)}\right]$, et il ne se tairait pas, il bavarderait, c'était certain! (Flaubert, Madame Bovary: 2, X, p. 155)

Det er klart at sætningen umiddelbart før højre virkefelt ikke kan udgøre venstre virkefelt, for hvilken primitiv følgerelation skulle kunne tillade læseren at ræsonnere sig frem til at Binet havde gættet hvorfra Emma kom alene ud fra en oplysning om at den sti hun kom ad kun førte til la Huchette (eller omvendt)? Måske er det for at gøre dette klart at Flaubert har placeret donc mellem det nominale subjekt og det finitte verbal. Denne placering af et sætningsadverbial som donc udvirker nemlig en form for fokalisering af subjektet, der præsenteres 
som udgørende et nyt tema lokalt, men som en genoptagelse af et tema nævnt tidligere i teksten. Det er interessant at bemærke at den lineære placering af donc i sætningen der udgør venstre virkefelt på denne måde fungerer som en slags vejviser for detektionsfunktionen. Vi føres så at sige automatisk til at lede efter sidste gang Binet blev nævnt, og det skete netop i den sætning der er foreslået som venstre virkefelt, og som i øvrigt netop også er den første sætning der er del af den dækkede direkte tale som gengiver Emmas tanker ${ }^{14}$. Ved nærmere eftertanke viser det sig imidlertid at heller ikke denne sætning alene kan udgøre venstre virkefelt. Der er snarere tale om en kombination af denne og sætningen lige foran donc. Eller måske simpelthen af hele passagen fra Sans doute til Huchette. Eksempel (17) synes altså at vise at venstre virkefelt kan udgøres af et større tekststykke, hvoraf læser så kan uddrage det argument der passer ind i L-Sfunktionen $^{15}$.

I det næste eksempel kan man vakle mellem to læsninger svarende til to forskellige venstre virkefelter:

(18) $\left[_{\mathrm{x} 1(\mathrm{p})}\right.$ Elle confondait, dans son désir, les sensualités du luxe avec les joies du coeur, l'élégance des habitudes et les délicatesses du sentiment..$\left._{\mathrm{x} 1(\mathrm{p})}\right]\left[_{\mathrm{x} 2(\mathrm{p})} \mathrm{Ne}\right.$ fallait-il pas à l'amour, comme aux plantes indiennes, des terrains préparés, une température particulière $\left.?_{\mathrm{X}(\mathrm{p})}\right]\left[{ }_{\mathrm{Y}(\mathrm{q})}\right.$ Les soupirs au clair de lune, les longues étreintes, les larmes qui coulent sur les mains qu'on abandonne, toutes les fièvres de la chair et les langueurs de la tendresse ne se séparaient donc pas du balcon des grands châteaux qui sont pleins de loisirs, d'un boudoir à stores de soie avec un tapis bien épais, des jardinières remplies, un lit monté sur une estrade, ni du scintillement des pierres précieuses et des aiguillettes de la livrée. $_{\mathrm{Y}(\mathrm{q})}$ ] (Flaubert, Madame Bovary: 1, IX, p. 92)

Begge læsninger virker lige sandsynlige. Man kan forestille sig at dette er en bevidst effekt fra Flauberts side. For at forstå teksten skal man inddrage begge strukturer i sin læsning. Man bemærker i øvrigt at det ikke er muligt at analysere $X_{1}$ og $X_{2}$ som udgørende ét stort virkefelt. De to tekstpassager har nemlig hver sin status; $X_{1}$ er forfatterberetning og $X_{2}$ dækket direkte tale. Alligevel er der en klar sammenhæng mellem de to sætninger, idet $X_{2}$ er foregrebet direkte af $X_{1}$.

I begge disse eksempler udgøres venstre virkefelt altså af flere ytringer, og i en vis forstand er det snarere hele den fiktive situation der opmales af de berørte tekststykker som udgør venstre virkefelt. Det er et element fra denne "tekstsituation" der er antecedent i L-S-relationen. Derved udtrykker 
eksemplerne en slags overgang til et fænomen der er udbredt i talesproget, hvor antecedenten faktisk ofte udgøres af en situation snarere end af et verbalt udtryk. Det gælder fx i (19):

\section{(19) Tu n'as $\underline{\text { donc }}$ rien compris.}

Hvor det er modtagers foregående verbale - og måske nonverbale - reaktioner der foranlediger taler til at konkludere ved hjælp af donc at han altså intet har forstået. Denne konklusive anvendelse af donc er også udbredt i skriftsprog; men i talesprog er det ikke den eneste anvendelse med nonverbalt venstre virkefelt. Vi har det samme i en ytring som (20), som jeg vender tilbage til i næste afsnit:

Donc, revenons à nos moutons.

(20) betyder noget i retning af 'Nå, skal vi vende tilbage til emnet?'.

Nonverbalt venstre virkefelt er i det hele taget ikke spor ualmindeligt i talesprog, hvor hele udsigelsessituationen og -konteksten tilsyneladende kan gå ind og erstatte det verbale udtryk. Vi har det samme med mais:

(21a) Mais qu'est-ce que tu fais là?

(21b) Mais!

I (21a) er argumentet qu'est-ce que tu fais là? en reaktion på noget i situationen (en handling som modtager er i færd med), og i (21b) kan man sige at det er noget tilsvarende, blot er selve reaktionen nu heller ikke udtrykt direkte verbalt men kun ved intonationen, der angiver overraskelse. Det eneste der er verbaliseret, nemlig ved hjælp af mais, er en bestemt forbindelse mellem noget i situationen og afsenders reaktion på det. Begge disse nonverbale størrelser tolkes af konnektoren. De nævnte eksempler er helt almindelige og frekvente i talesprog; men de svarer, som det fremgår, ikke til vores beskrivelse af den prototypiske konnektor, der forbinder ytringer. Imidlertid etablerer de også i disse tilfælde en relation mellem to størrelser, også i disse tilfælde har de en antecedent og en konsekvent. Blot skal (nogle af) disse argumenter ikke udledes af ytringer, men af situationer. Det er også helt klart at den relation der etableres er parallel med den konnektorerne skaber i deres såkaldte prototypiske anvendelser. I sådanne tilfælde forekommer det teoretisk hensigtsmæssigt at 
regne med, at det stadig drejer sig om samme konnektorer, de har blot nonverbale virkefelter. I stedet for at tale om at ordene skifter funktion og bliver til fx diskurspartikler, er det på alle måder teoretisk mere tilfredsstillende at sige at de tager et nonverbalt virkefelt. En situation er jo med alt hvad den indeholder også en formel størrelse. De berørte situationer befinder sig pænt lige før og lige efter konnektoren ligesom de verbale virkefelter gør det, og det hele kan klares ved at man taler om dem som en særlig type virkefelt. Denne tilgang udvider også konnektorgrammatikkens beskrivelses- og forklaringspotentiale. Således ville en undersøgelse af hvilke konnektorer der tager hvilke former for virkefeltsperspektiver være et overordentligt interessant projekt.

Denne metodediskussion tages op igen i afsnit 8. Her skal jeg lige pege på et spørgsmål der straks trænger sig på når man sammenligner eksemplerne med donc og dem med mais: Kan man også finde donc med to nonverbale virkefelter? Tilsyneladende har vi følgende mønster:
a. $\underline{\text { Mais! }}$
b. * Donc!
c. Donc?
d. Mais?

Intuitivt er donc alene muligt med spørgende intonation som i (22c). Konsekvensen må så være det forventede svar - det er modtager der opfordres til at drage en konsekvens ${ }^{16}$. Til gengæld forekommer donc alene umuligt med udråbsintonation som i (22b). Mais synes derimod at acceptere begge intonationsmønstre. Også her ligger der et spændende forskningsområde.

\section{DONC}

Hvis man, som jeg netop har foreslået, accepterer at en konnektor kan have nonverbalt virkefelt, så har det nogle konsekvenser for formuleringen af dens LS-funktion. Er det overhovedet muligt at formulere denne på en måde der dækker alle den berørte konnektors verbale og nonverbale anvendelser? Hvis dette ikke er tilfældet, svækkes argumentationen for at tale om konnektorfuntion i alle tilfælde. Lad os derfor som eksempel se nærmere på donc i dens forskellige anvendelser. Vi kan her støtte os til de mange undersøgelser donc har været underkastet. Så vidt jeg ved, var Anna Zenone (1981) den første 
der foretog en detaljeret undersøgelse af dette lille ord. Hun oplistede fem forskellige anvendelser:

- $\quad$ Genoptagelses-donc: Angivelse af at et tidligere diskurstema genoptages.

- $\quad$ Diskursivt donc: Typen Que ta maison est donc jolie! ('Hvor er dit hus dog kønt!').

- $\quad$ Argumentativt donc: Den "logiske" type vi så i (13) Il fait beau, donc Pierre se promène.

- $\quad$ Metadiskursivt donc: Typen C'est votre point de vue donc que vous êtes en train d'énoncer? ('Det er altså deres eget synspunkt de er i færd med at udtrykke?')

- $\quad$ Rekapitulerende donc, der benyttes til at angive en rekapitulation af en længere tekstpassage.

Siden Zenones pionerarbejde har adskillige lingvister forsøgt at præcisere hvad donc betyder ${ }^{17}$. Man har afdækket eksistensen af mange forskellige anvendelser, og man har forsøgt at afgøre om det drejer sig om kontekstuelle betydninger der alle kan føres tilbage til samme grundbetydning eller om man er nødt til at acceptere eksistensen af flere homonyme donc. På trods af de store teoretiske forskelle der er mellem disse arbejder har de alle til fælles at de koncentrerer sig om donc's betydning, dvs. om dens L-S-funktion, og slet ikke tager fat på konnektorens strukturelle egenskaber, endsige på afgrænsningsproblematikken, der involverer det helt fundamentale spørgsmål "Hvad er en konnektor?"

Det er en slags ekstrakt af disse arbejder der har inspireret mig til at formulere den L-S-funktion for donc som jeg nævnte i 3.3.:

(15) I sekvensen $X$ donc $Y$ præsenteres $Y$ som en konsekvens af $X$ fundet ved et ræsonnement.

Denne formulering gør rede for at donc tillader begge rækkefølger af den primitive følgerelations argumenter som vi så det i 3.2.:

(13a) Il fait beau, donc Pierre se promène. (p donc $q)$

'Det er godt vejr, altså går Peter en tur.'

(13b) Pierre se promène, donc il fait beau.

$(q$ donc $p)$

'Peter går en tur, altså er det godt vejr.' 
I det hele taget synes (15) at give en udmærket beskrivelse af den L-S-relation donc har i tekster. Det er imidlertid mindre oplagt at den også kan anvendes på forekomster med nonverbalt venstre virkefelt som i følgende eksempler:

(19) Tu n'as donc rien compris.

'Du har altså ikke forstået noget.'

(20) Donc, revenons à nos moutons!

'Nå, skal vi vende tilbage til emnet?'

(23) Je déclare donc la réunion ouverte.

'Jeg erklærer mødet for åbnet.'

(24) Donc, cette image représente ...

'Dette billede repræsenterer ...'

(25) Que ta maison est donc jolie!

'Hvor er dit hus dog kønt!'

(26) Mange donc!

'Spis dog!'

(27) Que voulez-vous donc?

'Hvad vil De dog (have)?'

(23) kan bruges i en situation hvor sidste mødedeltager lige er kommet ind ad døren, og (24) hørte jeg i den forhistoriske Niaux-grotte i Sydfrankrig, hvor guiden sagde det hver gang hun skulle til at forklare et af hulemalerierne. Hvad er egentlig antecedenten i disse eksempler, hvis der da overhovedet er tale om en konnektorfunktion?

\subsection{Donc's venstre virkefelt: Detektionsfunktionen}

Inden vi kan sige noget nærmere om det, er vi imidlertid nødt til at se nærmere på hvad det er for størrelser der udgør donc's (eventuelle) venstre virkefelt i disse tilfælde og på hvordan vi finder dem. I (19) viser donc at ytringen den ledsager er 
en konklusion taler drager ud fra modtagers reaktioner og/eller bemærkninger. Venstre virkefelt udgøres altså af modtagers handlinger (verbale og nonverbale). (20) kan minde lidt om (19) for så vidt som donc også her angiver en reaktion på - denne gang samtalepartnerne som helhed's - (verbale) optræden. Den egentlige konkluderende nuance er dog væk. (23) er lidt anderledes. Her synes donc at angive at nu hvor alle (af betydning) er til stede kan mødet åbnes. (24) viser sig at ligne (23). Umiddelbart kunne det virke som om guidens brug af donc blot er et tic; men ved nærmere eftersyn viste det sig ikke at være så enkelt. Ytringen med donc faldt nemlig hver gang netop i det øjeblik hvor den sidste gæst var nået frem til billedet hvor guiden stod. Donc ser altså ud til at være guidens (sikkert helt ubevidste) markering af at nu hvor alle var til stede kunne hun godt begynde forklaringen. Eksempel (25) er vanskeligere. I dette har donc en eksklamativ værdi, ofte med en nuance af overraskelse. Det synes dog klart at (25) kun er mulig i en situation hvor taler lige har set huset, så venstre virkefelt må være denne hændelse, evt. plus en tidligere kognitiv tilstand hos taler, som gør at synet af huset er lidt uventet. I (26) knytter donc an til modtagers attitude (over for omtalte spisehandling), og det samme kan vel siges om (27). I begge tilfælde misbilliger taler i en vis grad denne attitude.

I alle syv tilfælde angiver donc altså eksistensen af noget nonverbalt der går umiddelbart forud for udsigelsen af donc. I tilfælde hvor den sætning donc er knyttet til indeholder en henvisning til diskursens parter, og mere specifikt til modtager, er der tale om en situation der direkte - og tilsyneladende udelukkende - involverer disse (denne). Donc refererer i alle tilfælde til denne situation, og der er derfor på det formelle plan intet i vejen for at opfatte donc som en konnektor i alle tilfælde, hvis man accepterer at operere med nonverbale virkefelter således som jeg foreslog det i afsnit 5 .

Vi har altså set at donc's venstre virkefelt kan være en enkelt sætning, et tekstfragment eller en ekstralingvistisk situation. Er det på dette grundlag muligt at formulere donc's detektionsfunktion? Det ser faktisk ud til at de tre typer virkefelter befinder sig i en form for indbyrdes hierarkisk forhold, således at man har en stærk tendens til om muligt at vælge sætningen umiddelbart foran donc som venstre virkefelt og først i sidste ende stiller sig tilfreds med noget nonverbalt. Med hensyn til varianten 'tekstfragment' så vi at dette fragment tilsyneladende altid udgør en sammenhængende enhed på tekstplan; man 
kunne næsten tale om at det fungerer som én udvidet ytring. Under forudsætning af at disse antagelser holder, kan man derefter foreslå følgende formulering af donc's strukturelle funktioner:

\section{Donc's virkefelter}

- $\quad$ Donc har to virkefelter, ét til venstre, $X$, og ét til højre, $Y$.

- $\quad Y^{\prime}$ s udstrækning er den sætning donc er knyttet til syntaktisk.

- $\quad Y^{\prime}$ s perspektiv er 'ytring'. $Y$ udtrykker i øvrigt altid et afsendersynspunkt ${ }^{18}$.

- $X^{\prime}$ s udstrækning er en sætning, et tekstfragment eller de umiddelbare ekstralingvistiske omgivelser.

- $\quad X^{\prime}$ s perspektiv er 'ytring' i de to første tilfælde og 'situation' i det sidste.

Tanken der ligger bag adskillelsen af virkefeltsudstrækning og virkefeltsperspektiv i det nonverbale tilfælde er at instruksen som udgangspunkt siger: "Søg i den nærmeste ekstralingvistiske kontekst". Det er en rent formel størrelse. Dernæst skal man uddrage et særligt aspekt af denne formelle størrelse, nemlig en situation. Det er så denne der giver anledning til at udvinde det argument L-S-funktionen har brug for. Det er helt klart at dette teoretiske apparat kræver at man foretager en nøje gennemarbejdelse for at se om det kan virke og om det er teoretisk forsvarligt. Det vil jeg imidlertid lade ligge her og i stedet se på detektionsfunktionen. Denne udnytter det hierarkiske forhold mellem de tre (hoved)varianter af virkefelt:

\section{(29) Donc's detektionsfunktion}

Styrende princip: Find et $X$ der tillader at udlede et argument, $p$, som kan føre til en tilfredsstillende tolkning af $p$ donc $q$ i overensstemmelse med LS-funktionen.

1. Brug den sætning der står umiddelbart foran $Y$ (hvis der er en)!

2. Gå længere tilbage i den monologale tekst indtil du råder over et tilstrækkelig stort tekstfragment til at udlede $p$ !

3. Led i de umiddelbare ekstralingvistiske omgivelser efter elementer der kan udgøre den situation som $p$ kan udledes fra!

I det nonverbale tilfælde vil $Y$ ofte indeholde ret præcise supplerende anvisninger, som fx tilstedeværelsen af et andenpersonspronomen, en bydeform eller lignende, som pejler hen mod en situation bygget op omkring modtager. 
Bemærk i øvrigt at man automatisk kommer til punkt 3. i de tilfælde hvor der ingen tekst er der går forud for $Y$, men at detektionsfunktionen også forudsiger muligheden af at nå til punkt 3. efter en forkastelse af punkterne 1 . og 2 .

\subsection{Donc's logisk-semantiske funktion}

Med indførelsen af nonverbale virkefelter ser det altså ud til at være muligt at regne donc for en konnektor i alle de anvendelser vi har set på her. Men er der tale om én konnektor eller om flere forskellige? Med andre ord, koder donc en form for grundbetydning, udtrykt som en fælles instruks, i alle tilfælde? Er det muligt at formulere donc's L-S-funktion så den virker i alle tilfælde, dvs. således at de iagttagede forskelle alene, og på systematisk vis, kan henføres til de forskellige kontekstuelle og situationelle omgivelser donc forekommer i?

Ser vi nærmere på alle eksemplerne, synes et fællestræk at være at donc angiver at nu er taler klar til at ytre $Y$. Hvis dette holder stik, kan man foreslå følgende formulering af donc's L-S-funktion:

(30) Donc's L-S-funktion

I sekvensen $X$ donc $Y$ præsenteres argumentet der er formidlet gennem $X$ som opfyldende en tilstrækkelig betingelse for sproghandlingen (udført af) $Y$ (i Searles forstand).

Lad os se lidt nærmere på om (30) dækker alle de eksempler vi har iagttaget.

I den klassiske logiske anvendelse som vi så i (13):

(13a) Il fait beau, donc Pierre se promène.

(deduktion)

(13b) Pierre se promène, $\underline{\text { donc }}$ il fait beau.

(abduktion)

udfører $Y$ en assertiv sproghandling. Her angiver $X$ den nødvendige "logiske" forudsætning for at udføre assertionen af $Y$. Det er altså det faktum at taler har konstateret indholdet af $X$, der gør det muligt for ham at ytre $Y$. Der er ifølge taler en "logisk" forbindelse mellem $X^{\prime}$ 's og $Y^{\prime}$ s indhold, således at hvis man har det ene, så ved man (ved deduktion) eller kan man formode (ved abduktion) at man også har det andet. Konstateringen af det ene arguments realitet åbner altså for udførelsen af et ræsonnement der leder til det andet. At L-S-funktionen foreslået i (30) taler om sproghandling og ikke om indhold, tillader os således at 
forudsige at både deduktion og abduktion er mulig, når begge argumenter er propositioner.

I eksemplerne hvor $X$ udgøres af et (større) tekstfragment synes (30) også at fungere. I disse tilfælde er det klart at sproghandlingen let kan få egentlig konkluderende værdi; men andre nuancer er også mulige. Sammen med Michel Olsen har jeg studeret en række sådanne eksempler (Nølke \& Olsen 2000), og det var påfaldende at den mest nærliggende læsning i alle tilfælde var den deduktive. Der synes intet at være til hinder for at abduktionseksempler også skulle kunne forekomme; men om det rent faktisk er tilfældet er indtil videre et åbent spørgsmål.

Det er jo anvendelserne med nonverbalt virkefelt der har givet inspiration til formuleringen i (30). Som vi så i 6.1., er ytringen af $Y$ i alle tilfælde en reaktion på konstateringen af noget i situationen som går umiddelbart forud. De forskellige værdier donc er blevet tillagt, konkluderende (se (19)), markerende overraskelse (se (25)), irritation (se (27)) osv., kan så forklares ved Y's form og indhold. Lad os tage (27) som eksempel. Uden donc ville spørgsmålet være et helt neutralt spørgsmål - i hvert fald hvis det ytres med neutral intonation -; men donc angiver altså (i den mest nærliggende læsning) at det er foranlediget af modtagers handlen umiddelbart før spørgsmålet, en handlen der måske involverer taler på en eller anden måde. Denne handlen har åbenbart givet taler anledning til at formode at modtager har et skjult formål, hvilket naturligt må irritere. Man kan forklare alle de andre eksempler vi har set på på tilsvarende måde. Vi kan derfor konkludere at formuleringen i (30) har gjort det mulig at bibeholde ideen om ét donc, der blot er stærkt kontekstfølsomt, og som derfor kan give anledning til en stribe forskellige læsninger.

Men hvad med eksemplet i (22), hvor også $Y$ er nonverbalt?

$$
\begin{aligned}
& \text { b. }{ }^{\star D o n c !} \\
& \text { c. Donc? }
\end{aligned}
$$

Vi så at donc her nok kun er mulig med spørgeintonation, og dette passer faktisk glimrende med formuleringen i (30). Et spørgsmål lægger jo op til et svar, som så udgør $Y$. Donc's funktion er så at angive at nu er betingelserne (faktisk!) opfyldt 
for at modtager kan give svaret. Men hvorfor skulle taler ønske at insistere på det? De normale betingelser for at stille et spørgsmål er at afsender formoder at modtager er i stand til at svare på det, dvs. at betingelserne for at han kan svare er opfyldt. Når taler insisterer på det alligevel, vil det altid give en særlig betydningseffekt. En kan fx være at taler på denne måde anmoder modtager om at drage en konklusion af noget han lige har sagt. En anden kan være at han ønsker at modtager skal reagere på noget der lige er sket - fx det at en tredje person har opfordret begge til at foretage sig noget - eller at taler har opfordret modtager til det. Mulighederne er legio; men igen synes de alle styret af L-Sfunktionen som den er formuleret i (30).

(30) ser således ud til at fungere i alle donc's anvendelser. I tilfældene med nonverbalt virkefelt hvor der ikke - i hvert fald ikke umiddelbart - er tale om noget propositionelt indhold, kan man imidlertid næppe tale om en logisk funktion i normal forstand. Derfor er der heller ikke tale om et ræsonnement som sådan, hvilket formentlig medfører at rækkefølgen af argumenterne nødvendigvis er den samme som i den primitive følgerelation (dvs. at $X$ formidler $p$ og $Y$ formidler $q$ ). Hvis dette er rigtigt, har man derfor i disse tilfælde altid en form for deduktion og ikke abduktion. Om abduktion trods alt også findes i disse anvendelser er dog et empirisk spørgsmål (tror jeg).

Et andet spørgsmål er selvfølgelig om det overhovedet er rimeligt at tale om en Logisk-Semantisk funktion når der er nonverbalt virkefelt. Dette spørgsmål vender jeg tilbage til i afsnit 7.1.19

\section{SYLLOGISMEN OG DE "LOGISKE" KONNEKTORER}

Mange studier af donc har taget deres udgangspunkt i konnektorens konventionelle anvendelse i syllogismen, hvor den ledsager konklusionen. Standardeksemplet er:

\section{(31) I. Tout homme est mortel.}

II. Or Socrate est un homme.

III. Donc Socrate est mortel.

Ideen er at denne anvendelse i en eller anden forstand er den fundamentale, som alle de andre kan udledes fra. Noget lignende er i øvrigt gjort mht. or af 
Gettrup et al. (1986), der har forslået en analyse, hvori alle or's anvendelser kan føres tilbage til dens introduktion af underpræmissen i syllogismen. Spørgsmålet er nu om donc's anvendelser med nonverbalt virkefelt også kan forklares eller beskrives ved hjælp af syllogismeideen.

\subsection{Den "generaliserede syllogisme"}

Det er klart at dette ikke kan lade sig gøre umiddelbart. For det første er der her ingen underpræmis i logisk forstand, og endnu vanskeligere forekommer det at være at tale om en overpræmis. Hvad skulle det være? Syllogismeideen har dog, synes jeg, noget umiddelbart "rigtigt" over sig. Syllogismen gengiver i en eller anden forstand et generelt ræsonneringsmønster som man genfinder i mange former for sproglig kommunikation, og det gør det forsøget værd at prøve at redde den. En måde kunne være at "propositionalisere" kommunikationssituationen. Man kunne forsøge at beskrive antecedenten der udledes af det nonverbale venstre virkefelt som en proposition. Jeg kan dog ikke se nogen mulighed for at operationalisere denne fremgangsmåde, og hvis den må bygge på ren intuition hos den der analyserer, synes mere tabt end vundet.

Imidlertid er der måske en anden udvej. Problemet er at syllogismen bygger på propositioner; men det er muligt at opgive denne forudsætning, alt imens man bevarer syllogismestrukturen. Jeg foreslår at tale om den generaliserede syllogisme:

(32) Den "generaliserede syllogisme"

- I. Generel regel 'A er en tilstrækkelig betingelse for B', symboliseret: $\mathrm{A} \rightarrow \mathrm{B}$.

- II. Konkret opfyldelse/manifestation af A.

- $\quad$ III. Konklusion/effekt: (altså) B er tilfældet/(kan) gennemføres.

Det der adskiller den generaliserede syllogisme fra den klassiske er udelukkende at kravet om at de tre elementer skal være propositionelle er opgivet. Den klassiske syllogisme bliver derved en variant af den generaliserede.

Analysen af donc falder pænt på plads i denne struktur. I tilfælde med verbalt venstrevirkefelt får den generelle regel formen af et topos som 'Når det er godt vejr går Peter en tur'. Som man ser, udtrykker dette topos netop den primitive 
følgerelation jeg talte om i 3.2. I tilfælde med nonverbalt virkefelt bliver reglen snarere noget i retning af 'Betingelse A skal være opfyldt for at udføre (sproghandling) B'.

Det kan faktisk godt se ud til at der er en systematisk sammenhæng mellem donc's virkefeltsperspektiver og formuleringen af regel I. Hvis dette er tilfældet, kan konnektorens L-S-funktion formuleres på følgende enkle måde:

\section{(33) Donc's L-S-funktion}

Donc ledsager konklusionen i den generaliserede syllogisme.

Donc's strukturelle funktioner kombineret med konnektorgrammatikkens helt generelle regel om at argumenterne udledes af virkefelterne gør så rede for de forskellige anvendelser donc kan have i konkret sprogbrug. Hvis fx donc får nonverbalt virkefelt, betyder det at A i regel (32 I.) er ikke-propositionel. Da den strukturelle funktion samtidig præciserer at højre virkefeltsperspektiv er 'ytring', betyder det at A må være et situationelt element der udgør en tilstrækkelig betingelse for udførelsen af denne ytring. ${ }^{20}$

Endelig kan vi konstatere at, for så vidt som den generaliserede syllogisme kan betragtes som en formalisering af et helt generelt ræssoneringsmønster, synes der dermed heller ikke at være noget i vejen for at bevare betegnelsen LogiskSemantisk funktion også i tilfælde med nonverbale virkefelter.

\subsection{Gruppering af konnektorer i grundtyper}

Måske kan ideen med den generaliserede syllogisme også benyttes i beskrivelsen af andre konnektorer end donc; ja, måske kan man ligefrem foreslå en gruppering af konnektorerne som bygger på deres placering i syllogismen. Ved at anvende forskellige forskeres resultater kan man nå frem til følgende skitse:

(34) Gruppering af konnektorer i grundtyper

- $\quad$ Type I. puisque, ...

- Type II. puisque, parce que, car, or, ... ('årsagskonnektorer')

- $\quad$ Type III. donc, c'est pourquoi, ... ('følgekonnektorer') 
Typenummeret angiver hvilket syllogismeelement konnektoren ledsager. Denne skitse er især inspireret af Olsen (2001), der har påvist at puisque er i stand til at ledsage såvel overpræmissen som underpræmissen, om end det sidste er langt det hyppigste. Olsen begynder således med at give de to følgende konstruerede og velformede eksempler:

\section{(35) 1. Socrate est mortel, puisqu'il est un homme.}

2. Socrate est mortel, puisque tous les homme sont mortels.

(Olsen 2001: 41)

De mange forskelle der er mellem konnektorerne i samme gruppe vil så formodentlig primært hænge på deres virkefelters natur. For eksempel kræver car (formentlig), i modsætning til or, et verbalt venstre virkefelt der skal formidle konklusionen i syllogismen.

Talrige studier underbygger at denne klassifikation holder (rimeligt?) så længe begge konnektorens virkefelter er verbale, så man falder tilbage på den klassiske syllogisme; men hvad sker der når vi har nonverbalt virkefelt? For donc's vedkommende har jeg argumenteret for at beskrivelsen stadig virker; men måske er der også andre relevante konnektorer der kan tage nonverbalt virkefelt? ${ }^{21}$ Dette er et stort og meget spændende spørgsmål som jeg imidlertid må lade ligge her i håbet om at kunne vende tilbage til det ved en senere lejlighed.

Vi kan dog umiddelbart konstatere mindst en klar begrænsning på beskrivelsesmetoden: Den virker kun for ensrettere. Modsatrettere som mais, par contre, toutefois, pourtant osv. har som regel en mere kompleks L-S-funktion. De involverer dog oftest ligeledes en idé om en underliggende generel regel. Dette er tydeligt i fx indrømmelsesstrukturer, hvor denne regel så blot bliver punktuelt tilsidesat, måske på grund af en konkurrerende regel der i det konkrete tilfælde er "stærkere". Dette spil kommer tydeligt frem ved konnektoren mais (jf. afsnit 3.). Her er endnu et punkt jeg håber at få lejlighed til at tage op ved en senere lejlighed.

\section{FOR TIDLIGT AT KONKLUDERE}

Inden for de seneste år har utallige analyser af konnektorerne set dagens lys, og de har afsløret at disse repræsenterer et overordentlig stort og kompliceret 
problemkompleks. Jeg har forsøgt i denne artikel at kortlægge nogle af de væsentligste områder og at skabe et begrebsapparat der måske kan anvendes i det fortsatte arbejde. Det er dog kun et ganske lille skridt der er taget. Således er der helt fundamentale spørgsmål der endnu trænger sig på. Lad mig nævne nogle af de vigtigste her:

Hvad er konneksion? Konneksion er et kohæsionsfænomen ligesom isotopier, anaforiske relationer osv.; men hvad er det der adskiller konneksion fra andre kohæsionsfænomener? Jeg har tidligere foreslået at hvor andre typer kohæsion skaber direkte relationer mellem de involverede tekstelementer, er konneksion karakteriseret ved at blive skabt af et element der snarere spiller rollen som formidler uden selv at deltage direkte i kohæsionsrelationen (Nølke 1993: 134) ${ }^{22}$. Konnektorerne tjener netop denne funktion; men det er der også andre elementer der gør. Jeg har så foreslået at udskille de analytiske konnektorer karakteriseret ved at konneksionen er deres primære funktion (jf. 2.2.). På denne måde får vi frasorteret adverbialer som oerlig talt, som vi så på i eksempel (8) i afsnit 2.2., og et første afgrænsningsproblem er løst.

Erkendelsen og accepten af at konnektorer kan tage nonverbalt virkefelt rejser imidlertid langt alvorligere afgrænsningsproblemer. Det måske alvorligste spørgsmål der trænger sig på er her:

Hvordan afgrænses klassen af konnektorer i forhold til diskurspartiklerne (eller diskursmarkørerne)? Her ligger virkelig et omfattende afklaringsarbejde og venter forude. Det er ikke noget problem at nogle ord evt. kan optræde i begge funktioner. Problemet ligger i at afgrænse hvornår de har den ene og hvornår den anden. En løsning kunne måske være simpelthen at sige at konnektorerne samtidig er diskurspartikler når de optræder med nonverbalt virkefelt. Denne løsning kræver at man opgiver den aristoteliske opdeling i disjunkte klasser; men den er der nok også mange andre grunde til at opgive på dette område, hvor en prototypetilgang synes langt mere frugtbar (se fx Hansens arbejder).

Prototypeløsningen ser umiddelbart meget fristende ud; men den medfører også en række alvorlige problemer. Den vil muligvis betyde at man bliver nødt til at regne med et kontinuum: "mere eller mindre konnektor" og "mere eller mindre diskurspartikel"; men derved mistes en høj grad af den operationalitet der netop 
er forsøgt indført med konnektorgrammatikkens formelle apparat. Forholdet til syntaks bliver det så muligvis også vanskeligere at beskrive. Det antages generelt at diskurspartikler syntaktisk set er helt løst tilknyttet sætningerne; ja, undertiden ledsager de slet ikke nogen sætning, men angiver snarere specielle diskursive bevægelser. Konnektorerne kan derimod sagtens være integreret syntaktisk, også når de har nonverbalt virkefelt. En fordel ved prototypeløsningen kunne imidlertid være at den åbner for at tale om at visse diskurspartikler er opstået ved grammatikalisering (eller pragmatikalisering) ud fra konnektor- eller adverbialfunktioner. Hansens undersøgelser viser klart at flere småord er tilbøjelige til at gennemløbe en sådan proces hvor de måske oprindelig - både i genetisk og i diakron forstand - har haft mere "integrerede" funktioner. Dette gælder for eksempel enfin (Hansen 2005).

Om end afgrænsningen til diskurspartiklerne utvivlsomt er det største afgrænsningsproblem, er der også problemer i forhold til de paradigmatiserende adverbialer som vi så et eksempel på i (9). Disses grundfunktion er at udvælge et element inden for et præsupponeret paradigme (med et særligt formål for øje); men et eller flere elementer fra dette paradigme kan udmærket være nævnt i den foregående tekst, hvorved adverbialet kommer til at fungere som en (analytisk) konnektor (Nølke 1983: 164-180).

Endelig er det klart at konnektorerne også har fællestræk med præpositionerne. Her er afgrænsningen dog nok lettere at foretage, nemlig ud fra rent morfosyntaktiske kriterier; men hvori består fællestrækkene?

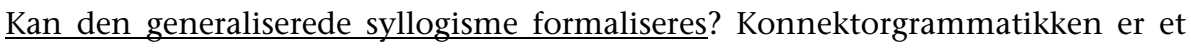
forsøg på at formalisere konnektorernes funktion(er) og operationalisere analyserne; men er dette også muligt hvis man accepterer den generaliserede syllogisme? Hvilket formelt apparat kan man ty til? Måske er dette problem dog knap så vigtigt i betragtning af at konnektorerne er funktionelt defineret.

Et helt andet spørgsmål, jeg slet ikke er kommet ind på her er:

Hvis synspunkter kommunikerer konnektorerne? For så vidt som i hvert fald de pragmatiske konnektorer jeg har behandlet i denne artikel involverer ræsonnementer, referer de til en logik; men hvilken logik er det, eller hvis logik er det? Dette er hele polyfoniproblematikken som Michel Olsen og jeg har 
behandlet i en række artikler, hvor vi har studeret specifikke konnektorer. Spørgsmålet har imidlertid ikke været studeret generelt i forhold til konnektorklassen som sådan. Det problem vender jeg tilbage til i Nølke (2006).

Der er vist ingen tvivl om at mine undersøgelser har rejst flere spørgsmål end de har besvaret. At studere konnektorerne er som at vandre i bjergene. Hver gang man tror man har nået en top, viser der sig ti nye toppe højere oppe, og det føles som om man ingen vegne er kommet; men udsigten bliver trods alt oftest smukkere for hvert skridt man tager. Der er lang vej endnu før vi når en forståelse af konnektorerne som gør det muligt for os for alvor at opstille deres grammatik. Jeg kan blot håbe at dette lille arbejde er et skridt i den rigtige retning; men ét er sikkert: Det er slet ikke tid at konkludere. ${ }^{23}$

\section{LITTERATUR}

Adam, Jean-Michel (1990), Éléments de linguistique textuelle; théorie et pratique de l'analyse textuelle, Liège: Mardaga.

Anscombre, Jean-Claude, Oswald Ducrot (1977), "Deux mais en français", Lingua, (1977), 43, pp. 23-40.

Blakemore, Diana (1987), Semantic Constraints on Relevance, Oxford: Blackwell.

Bruxelles, Sylvie et al. (1980), "Mais occupe-toi d'Amélie", i: Ducrot, Oswald et al. (eds.) (1980), Les mots du discours, Paris: Les Édition de Minuit, pp. 93-130.

Carel, Marion (2004), 'Occupe-toi d'Amélie': emploi contrastif de mais et illustration, (ms.).

Culioli, Andrée (1990), Pour une linguistique de l'énonciation, Paris: Orphys.

Ducrot, Oswald et al. (eds.) (1980), Les mots du discours, Paris: Minuit.

Fischer, Kerstin (2005), Approaches to Discourse Particles, Oxford: Elsevier.

Flaubert, Gustave (1971), Madame Bovary, Paris: éd. Class. Garnier.

Gettrup, Harald, Michael Herslund, John Pedersen, Arne Shnack (1986), Sprog \& Tekst. Studiebog i sagtekstanalyse, København: Københavns Universitet.

Hansen, Maj-Britt Mosegaard (1998), The Function of Discourse Particles. A study with special reference to spoken standard French, Amsterdam/Philadelphia: John Benjamins.

Hansen, Maj-Britt Mosegaard (2005), "La polysémie de l'adverbe toujours", Travaux de linguistique, (2005), 49, pp. 39-55.

Hansen, Maj-Britt Mosegaard (2005), "From prepositional phrase to hesitation marker. The semantic and pragmatic evolution of French enfin", Journal of Historical Pragmatics, 6:1, pp. 37-68.

Jayez, Jacques, Corinne Rossari (1996), "Donc et les consécutifs. Des systèmes de contraintes différentiels", Linguisticae Investigationes, XX (1996), pp. 117-143. 
Jørgensen, Kathrine Sørensen Ravn (1999), "Stylistique et polyphonie", Tribune, 9, pp. 21-36.

Le Draoulec, Anne, Marie-Paule Péry-Woodley, Laure Sarda (eds.) (2005), "L'organisation du discours à travers le temps et l'espace", Journal of French Lanuage Studies, 15.

Mellet, Sylvie, Michèle Monte (2005), "Néanmoins et toutefois: polyphonie ou dialogisme?", i: Bres, Jacques et al. (eds.) (2005), Dialogisme et polyphonie. Approches linguistiques, Bruxelles: Duculot.

Moeschler, Jacques (1985), Argumentation et Conversation. Éléments pour une analyse pragmatique du discours, Paris: Hatier.

Nyan, Than (1999), "Vers un schéma de la différence: le cas de mais", Journal of French Language Studies, 9, (1999), pp. 211-238.

Nølke, Henning (1990), "The Logic and Pragmatics of Connectors", HERMES, (1990), 5, pp. 69-95.

Nølke, Henning (1993), Le regard du locuteur. Pour une linguistique des traces énonciatives, Paris: Kimé.

Nølke, Henning (1994), Linguistique modulaire: de la forme au sens, Louvain/Paris: Peeters.

Nølke, Henning (1996), "A contrastive and argumentative analysis of the French connectors donc and car", Leuvense Bijdragen, 85, (1996), pp. 313-328.

Nølke, Henning (1997), Fransk Grammatik og Sprogproduktion, København: Kaleidoscope.

Nølke, Henning (1999), Det Franske Sprog, kapitel V, modifikation, foreløbig version.

Nølke, Henning (2001a), Le regard du locuteur 2. Pour une linguistique des traces énonciatives, Paris: Kimé.

Nølke, Henning (2001b), "Konnektorgrammatik", Ny Forskning i Grammatik, 8, (2001), pp. 191-205.

Nølke, Henning (2002), "Pour un traitement modulaire de la syntaxe transphrastique", VERBUM XXIV, 1-2, (2002), pp. 179-192.

Nølke, Henning (2006), “Connecteurs pragmatiques: l'apport de quelques connecteurs à la structure polyphonique", Le Français Moderne, 74.1, pp. 3242.

Nølke, Henning, Jean-Michel Adam (éds.) (1999), Approches modulaires: de la langue au discours, Lausanne/Paris: Delachaux et Niestlé.

Nølke, Henning, Michel Olsen (2000), "Donc pour conclure. Polyphonie et style indirect libre: analyses littéraire et linguistique", i: Actes du XIV Congrès des Romanistes scandinaves. CD-ROM et [www.hum.au.dk/romansk/polyfoni/pub. htm]

Olsen, Michel (2001), "Puisque: syllogisme caché", Revue Romane, 36 (2001), pp. 41-58.

Peirce, C. S. (1960), Collected Papers, Cambridge: Cambridge University Press. 
Rabattel, Alain (1999), "Mais dans les énoncés narratifs. Un embrayeur du point de vue et un organisateur textuel", Le français moderne, LXVII, 1, (1999), pp. 49-60.

Rossari, Corinne (1996), "Les marques de consécution: propriétés communes et distinctives à la lumière de donc, de ce fait et il en résulte que", i: Muller, Claude (éd.) (1996), Dépendance et intégration syntaxique, subordination, coordination, connexion, Tübingen: Niemeyer, pp. 271-283.

Rossari, Corinne (2000), Connecteurs et relations de discours: des liens entre cognition et signification, Nancy: Presses Universitaires de Nancy.

Rossari, Corinne, Anne Beaulieu-Masson, Corina Cojocariu, Anna Razgoulieva (2004), Autour des connecteurs. Réflexions sur l'énonciation et la porté, Bern: Peter Lang.

Roulet, Eddy (2001), Un modèle et un instrument d'analyse de l'organisation du discours, Bern: Peter Lang.

Zenone, Anna (1981), "Marqueurs de consécution: le cas de donc", Cahiers de linguistique française, 2, (1981), pp. 113-139.

Zenone, Anna (1982), "La consécution sans contradiction: donc, par conséquent, alors, ainsi, aussi (première partie)", Cahiers de linguistique française, 4, (1982), pp. 107-141.

\section{NOTER}

1 I alle artiklens eksempler fremhæver jeg den diskuterede størrelse (konnektoren) med understreget skrift.

2 I min behandling fra 1993 skelner jeg mellem "analytiske konnektorer", der svarer til de egentlige konnektorer, og de "syntetiske konnektorer", der kan være forskellige adverbialer som aerlig talt. Denne dybest set uheldige terminologi er blevet den officielle i Frankrig ved at være blevet optaget i Banque des mots.

3 Jeg foreslog termen 'paradigmatiserende adverbial' ('adverbe paradigmatisant') i min bog fra 1983, som så vidt jeg ved er det første arbejde der behandler disse størrelser under ét. Senere er de blevet kendt i angelsaksisk litteratur under termen 'Focus Particles', en term der på dansk er blevet til fokuspartiklerne. Denne term mister den vigtige pointe at det drejer sig om størrelser der syntaktisk på mange måder minder om sætningsadverbialer.

4 Se fx Maj-Britt Mosegaard Hansens forskellige arbejder samt Fischer (2005).

5 Et forskerhold i Toulouse med bl.a. Andrée Borillo og Anne Le Draoulec har arbejdet nogle år med de temporale konnektorer og det har hidtil resulteret i en række artikler og i et temanummer af JFLS: Le Draoulec et al. (2005).

6 Et forskerhold i Nice ledet af Sylvie Mellet har i nogle år arbejdet med de koncessive konnektorer. De har bl.a. publiceret Mellet \& Monte (2005) og er ved at færdigredigere en bog der forventes at udkomme i løbet af 2006.

7 Dette kapitel repræsenterer en videreudvikling af konnektorgrammatikken skitseret i Nølke (2001b).

8 Virkefeltsbegrebet (fransk 'la portée') indføres og uddybes i Nølke (1994).

9 Udtrykt i logiske termer tillader donc altså både deduktion (13a) og abduktion (13b). 
10 Lige siden Anscombre \& Ducrots artikel fra 1977 har konnektoren været studeret i alskens forskellige perspektiver. I direkte fortsættelse af Anscombre \& Ducrot (1977) ligger Bruxelles et al. (1980), som vel er blevet klassikeren, og senest Carel (2004). Disse arbejder studerer mais inden for sprogsystemet og har dannet udgangspunkt for en række analyser af mais's tekstfunktioner. Her kan især nævnes Adam (1990), Rabattel (1999) og Rossari et al. (2004). Den tidligere elev af Ducrot, Than Nyan, har undersøgt mais $\mathrm{i}$ et neurokognitivt perspektiv og endelig har Nølke et al. (2004) foreslået en polyfon analyse, der udbygges i Nølke (2006). Adskillige mindre og større arbejder har taget afsæt $\mathrm{i}$ disse analyser af mais. Det kan imidlertid også være interessant at sammenholde dem med fx Diana Blakemores analyse inden for rammerne af relevansteorien af det engelske but (Blakemore 1987).

11 I Lakoffs eksempel bliver denne særlige tolkning at republikanere normalt er uærlige, og dette er måske i virkeligheden afsenders hovedbudskab, som han således får pakket ind mellem linierne. Her opfører det engelske but sig ligesom det danske men og det franske mais (tysk aber, svensk men osv.). Paralleliteten er dog ikke altid så oplagt og et kontrastivt studie af de forskellige sprogs udtryk for men trænger sig på.

12 Ord som certes, eller det danske ganske vist betragter jeg ikke som konnektorer, men som "annonceurs"; de "annoncerer" at der kommer en særlig L-S-relation. Således bruges certes ofte til at annoncere en koncessiv relation.

13 Eksemplerne (17) og (18) har været genstand for mere dybdegående analyser i Nølke \& Olsen (2000). I begge tilfælde markeres virkefelterne ved hjælp af firkantede parenteser, hvor indeks også angiver om virkefeltet formidler antecedenten eller konsekventen i LS-relationen.

14 For en uddybende analyse, se Nølke (2001b).

15 Denne passage er struktureret som en intervention i Roulets forstand (Roulet et al. 2001) med første sætning som "hoved" eller "acte directeur".

16 Det kan være fordi modtager selv har lagt op til en konklusion han blot ikke har nævnt, eller det kan være fx i en eksamenssituation.

17 Især Culiolis, Hansens og Rossaris arbejder, som har anvendt tre helt forskellige teoretiske tilgange, har bragt megen ny indsigt. Rossari er flere gange vendt tilbage til konnektoren donc, og hendes bog fra 2000 indeholder en udmærket forskningsoversigt.

18 Det er derfor man meget vanskeligt kan have evidensmarkører som Il paraît que ("det siges at") i $Y$.

19 I mit første arbejde om konnektorgrammatik foreslog jeg, inspireret af Peirce, termerne 'deiktisk funktion' og 'ikonisk funktion' for henholdsvis de strukturelle funktioner og L-S-funktionen. Min begrundelse var: "I use the term iconic for the operational aspect of connectors because 'a great distinguishing property of the icon is that by the direct observation of it other truths concerning its objects can be discovered than those which suffice to determine its construction' (Peirce 1960, 279). This seems to me a good characterization of the general way in which expressions like but function: By introducing but between he is a Republican and he is honest, you do not learn anything new about but, but a lot about the two sentences" (Nølke 1990: 83).

20 Som et billede af udsigelsen kommunikerer en ytring både en illokutionær handling og et indhold.

21 Hvad puisque angår, så kan den i hvert fald have tekstfragmenter i sit venstre virkefelt; men i disse tilfælde fungerer den stadig efter syllogismeskemaet. Nonverbalt virkefelt er her nok vanskeligere at forestille sig. Konnektoren or ser derimod ud til ofte at have nonverbalt virkefelt. Dette er måske endda snarere reglen end undtagelsen, og det har foranlediget mange lingvister til slet ikke at betragte or som en konnektor, men derimod som en form for diskursmarkør. Man finder især or i to teksttyper, nemlig argumentative og eventyr(!). I de argumentative tekster ledsager or typisk det stærkeste eller afgørende argument, og her er der derfor næppe problemer med beskrivelsen. I 


\section{HVAD KONNEKTERER KONNEKTORERNE?}

eventyrene markerer or en "handlingskulmination", og hvis man her skal tale om en konnektorfunktion, må venstre virkefelt vel være (en del af) det handlingsforløb der går forud. Kan man tale om at det er nonverbalt?

22 Man kan sige at tekstfunktionen konneksion svarer til den syntaktiske funktion koordination. Det er derfor ikke overraskende at netop sideordnende konjunktioner altid fungerer som konnektorer når de forbinder hovedsætninger.

23 Marianne Hobæk Haff har læst en foreløbig version af denne artikel og er kommet med nogle kommentarer der har gjort det muligt for mig at undgå nogle alvorlige fejl. Resterende mangler er jeg naturligvis selv ansvarlig for. 